\title{
呼吸と心拍の信号強度を用いた濅姿勢識別の改善手法
}

\author{
松尾 一矢 ${ }^{* 1}$, 向井 利春*2, 郭 士傑*3
}

\section{A method for improving recognition of lying postures using a measured signal intensity of respiration and heartbeat}

\author{
Kazuya MATSUO*1, Toshiharu MUKAI ${ }^{* 2}$ and Shijie GUO*3 \\ ${ }^{* 1}$ Kyushu Institute of Technology \\ 1-1 Sensui-cho, Tobata-ku, Kitakyushu-shi, Fukuoka-ken 804-8550, Japan. \\ ${ }^{* 2}$ Meijo University \\ 1-501 Shiogamaguchi, Tempaku-ku, Nagoya-shi, Aichi-ken 468-8502, Japan. \\ ${ }^{*}$ Hebei University of Technology \\ Xiping Road No.5340, Beichen District, Tianjin 300130, China.
}

Received: 30 March 2018; Revised: 2 August 2018; Accepted: 22 October 2018

\begin{abstract}
We describe a method for improving recognition of lying postures using a measured signal intensity of respiration and heartbeat. We have proposed a measurement method of lying posture, respiration, and heartbeat using a Smart Rubber sensor, a rubber-based flexible tactile sensor sheet developed by us. We can obtain respiration and heartbeat by means of using the time series data of the body pressure measured at the suitable location determined by lying posture in this measurement method. Therefore, a recognition rate of lying postures and a measured signal intensity of respiration and heartbeat have positive correlation. In the experiments, we show that recognition of lying postures is improved by means of using a measured signal intensity of respiration and heartbeat.
\end{abstract}

Keywords : Unconstrained measurement, Lying posture, Respiration, Heartbeat, Rubber-based flexible tactile sensor sheet

\section{1. 序論}

日本では，2010 年から 2020 年までの 10 年間で, 65 歳以上の高齢者が約 2900 万人から約 3600 万人へと 700 万 人ほど増え, 社会全体の高齢化率も $23.0 \%$ から 29.1\%に増加すると予想されている (総務省統計局, 2011, 国立社 会保障・人口問題研究所, 2012). それに伴い, 要介護者も大きく増えると考えられるが, 介護職員の増加がそれに 追いつかないため，職員ひとりあたりの負担が大きくなると見込まれている (厚生労働省, 2011). したがって，介 護職員の負担を軽減してこの問題を解決するために，ロボット介護機器の導入の必要性が高まっている.

ロボット技術の介護利用における重点分野として，移乗介助，移動支援，排泄支援，認知症の方の見守り，入浴 支援の 5 分野が策定されている (経済産業省, 厚生労働省, 2012). このうちの認知症の方の見守りとして, センサ を用いて見守ることができれば，介護職員の負担軽減に大きく貢献できる．また，認知症の方に限らず，センサに よりベッド上の被介護者の状態を識別することの利点は多い. 識別すべき被介護者の状態としては, ベッドの上に いるかいないか，上体を起こしているか横になって休んでいるか，ベッドから転落する危険性はないか，寝姿勢

No.18-00175 [DOI:10.1299/transjsme.18-00175], J-STAGE Advance Publication date : 30 October, 2018

*1 正員, 九州工業大学 (

$*_{2}$ 正員, 名城大学 ( $4468-8502$ 愛知県名古屋市天白区塩釜口 1-501)

*3 河北工業大学（广300130 中国河北省天津市北辰区西平道 5340 号）

E-mail of corresponding author: kazu_matsuo@kyudai.jp 
は仰向けからつぶせかなどがある.さらに, 被介護者の体勢に加え, 眠りの深さなどの睡眠状態も計測できると 有用である. 睡眠状態を観測して睡眠の質を高めることは, 被介護者の健康状態を良好に保つのに効果的である. 睡眠状態を計測する方法として, 睡眠ポリソムノグラフィ検査 (Polysomnography: PSG) が最も信頼できる基準 とされている (日本睡眠学会, 2015, 野田, 古池, 2008). この手法は, 脳波, 心電図, 眼球運動, 頣筋電図, 呼吸 曲線を測定し，R\&K 法 (Rechtschaffen and Kales, 1968) に基づいて, 睡眠状態を覚醒，レム睡眠，ノンレム睡眠ス テージ 1 4 の 6 段階に分類するものである. 高い精度で睡眠状態を計測できるという利点があるが，一方で複数 の生体信号を測定するために多くのセンサを体に取り付けなければいけないため, 計測に拘束感が伴い, 自然な 睡眠を妨げる恐れがある. また, 生体信号から睡眠状態を識別するために検查技師の判断が必要であり, 自動化 が困難であるという問題もある。ゆえに, 被験者に負担をかけることなく, 睡眠状態を簡便に推定できる手法の 開発が求められている.

呼吸数, 心拍数, 体動数, 寝姿勢といった比較的に簡易に計測できる生体情報から, 睡眠状態を推定できるこ とが知られている (日本睡眠学会, 1999). 例えば, 心拍数と睡眠状態との間には, 強い相関があることが認められ ている (渡邊, 渡辺, 2001). また, 呼吸数や体動数は睡眠状態との関係が強い (Deguchi and Hagiwara, 2011, Otsuka et al., 1983). 他にも，側臥位で寝ることにより，睡眠時無呼吸症候群などの呼吸障害が起きにくいことが知られ ている (Beattie et al., 2011). そのため, これらの生体情報を用いて, 無拘束かつ非侵襲に睡眠状態を推定する手法 が，数十年前からいくつも報告されている (Alihanka et al., 1981, Salmi and Leinonen, 1986). Watanabe ら (2004, Kurihara and Watanabe, 2012b) は, 空気圧方式のマットレス型センサ (Kurihara and Watanabe, 2012a, Watanabe et al., 2005) を用いて心拍, 呼吸, 体動, イビキ, 咳を測定し, レム睡眠時に呼吸数と心拍数が増加してリズムが不 規則になることから睡眠状態を推定する手法を開発している，他にも，赤外線モーションセンサやカメラを用い て測定した体動の大きさと頻度に着目し, 睡眠の深さを評価した研究 (Kambayashi and Hagiwara, 2012, Okada et al., 2008) や, 呼吸数と心拍数から睡眠段階を評価した研究 (Harper et al., 1987) もある. また, 森屋ら (2008) は心 拍数のみから睡眠状態を推定する手法を報告している.

我々も，柔軟面状触覚センサを用いて寝姿勢 (向井他, 2014) および呼吸と心拍 (松尾他, 2015) を計測する手法を 提案している。これは, 我々が開発したゴム製の柔軟な静電容量型触覚センサ (Guo et al., 2012)（Smart Rubber セ ンサ，以下 SR センサと呼称）を用いて，ベッド上に横になっている人の寝姿勢と呼吸と心拍を無拘束に計測する ものである. まず, 体圧分布のパターンである触画像から寝姿勢を識別し, その識別結果に応じた体の位置の圧力 を測定することで呼吸と心拍を求めている. 空間分解能と圧力分解能が高いSR センサを用い, 測定した圧力情報 を適切に利用することで，寝姿勢と呼吸と心拍を同時に計測できる．また，厚さが数 $\mathrm{mm}$ とエアマットよりずっ と薄く, カメラとは異なりプライバシーに配慮した計測が行えるという利点もある.さらに, SR センサは既存の 測定装置より安価で設置に手間もかからないので, 日常的に利用しやすい.

SR センサを用いて計測した寝姿勢および呼吸と心拍から睡眠状態を推定したいが，実際にはそれらの生体情報 を必ずしも正しく計測できるとは限らないという問題がある. 例えば, 心拍は圧力変動が小さいため, 呼吸や体 動による変動やノイズに埋もれやすく計測しにくい. また, 体格や寝方の違いから, 寝姿勢の識別に失敗するこ ともある。

我々の手法では, 寝姿勢の種類に応じた位置の圧力情報を用いるため, 寝姿勢識別に失敗すると呼吸と心拍の 計測にも失敗してしまう可能性が高い, 逆に考えると, 計測された呼吸と心拍の信号強度が強い場合は, 寝姿勢 の識別に成功していると推定できる。 そこで本稿では, 計測された呼吸と心拍の信号強度を用いた寝姿勢識別の 改善手法を提案する. まず, 以前に我々が開発した手法において, 寝姿勢識別の成否と呼吸および心拍計測の成否 との間に相関があることを確認する, それから, 触画像から機械学習によって得られる確信度に加えて, 呼吸と 心拍の信号強度を用いることで, 寝姿勢の識別性能を改善寸る手法を提案し, 実データを用いた害験を行って提 案手法の有効性を示す，そして，最後にまとめを行なう。 


\section{2. 触画像および呼吸と心拍の信号強度を用いた寝姿勢の識別手法}

\section{$2 \cdot 1$ 呼吸と心拍の計測手法}

初めに，柔軟面状触覚センサを用いて測定した圧力情報から，人の呼吸と心拍を計測する手法 (松尾他, 2015) に ついて説明する（図 1). まず, ベッドに敷いた触覚センサを用いて, 横になっている人の体圧を測定する. 次に, 胸部などの適切な位置のセンサセルが測定した体圧の時系列データに対して, 周波数解析を適用する. この周波 数解析には, 高速フーリエ変換（Fast Fourier Transform, FFT）を用いた。 そして, 適切な周波数帯域を抽出する ことで，人の呼吸と心拍を取得する.

計測対象である人は, ベッド上で安静にしているものとした. 安静にしているとき, 呼吸と心拍はほぼ一定の周 期を保つ.また安静時には, 呼吸の周波数帯域と心拍の周波数帯域は重ならないので, 帯域フィルタなどを用いる ことにより分離できる．なお，抽出する呼吸と心拍の周波数帯域は，予備実験により以下のように決定した。(1) 呼吸の周波数帯域は，0.1[Hz] 0.4[Hz]（6[回/分]～24[回/分]）とする. (2) 心拍の周波数帯域は，0.8[Hz] 1.6[Hz] （48[回/分] 96[回/分]）とする. 抽出した周波数帯域を時間領域の信号に戻すことで, 呼吸と心拍の波形を求める ことができる. また, 呼吸数と心拍数のみを求める場合には, FFT 後に該当する带域内における卓越周波数を求 めればよい.
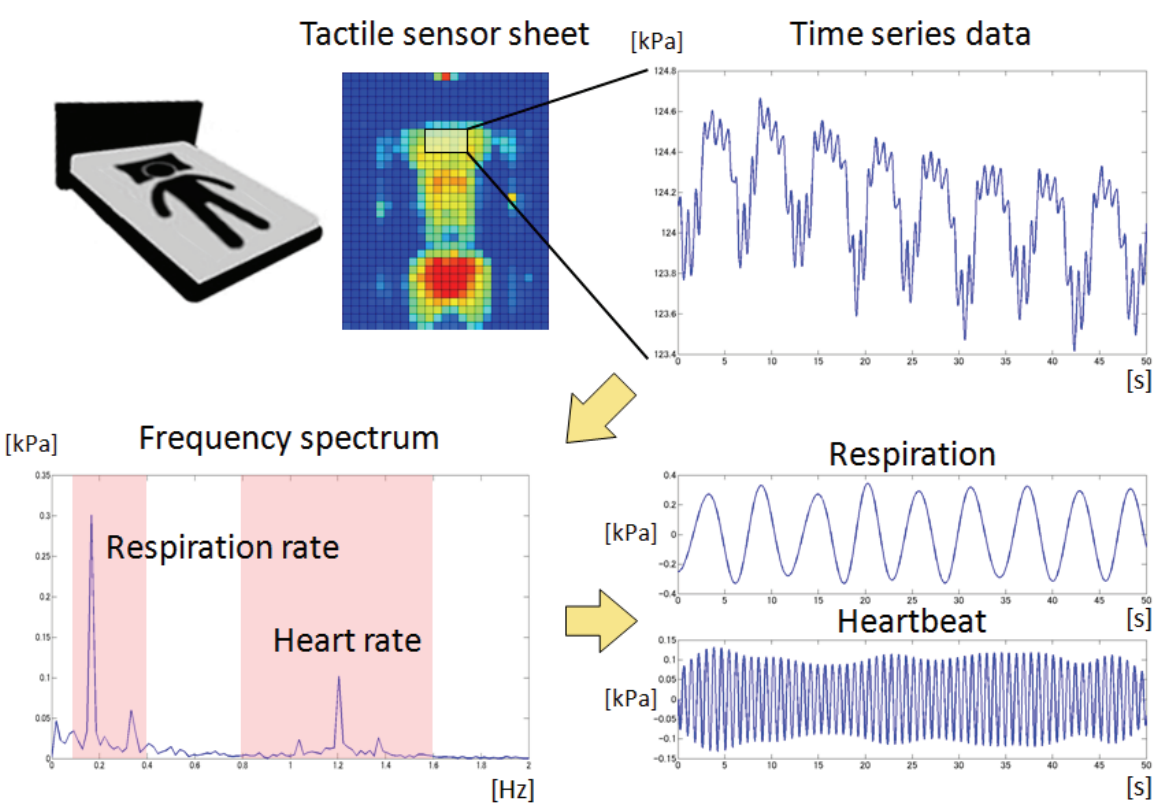

Fig. 1 Measurement method of respiration and heartbeat using a flexible tactile sensor sheet.

呼吸と心拍を正確に計測するためには，胸部などの適切な位置の体圧を測定する必要がある。そこで，機械学 習である AdaBoost(Freund and Schapire, 1997) を用いて寝姿勢を識別し，その結果に応じた位置（図 2）の体圧を 測定する，そうすることで，寝姿勢の変化に頑健な呼吸と心拍の計測を実現した (向井他, 2014). なお，図 2 に示 す計測に適切な位置とは, 実際に 11 人の被験者による計測を行い, 全被験者で心拍のピークが見られた位置であ る. 詳細については向井らの論文 (2014) を参照されたい. 本稿では, 図 2 において楕円で示されている範囲内で, 最も圧力が大きい位置の体圧データを用いた.

寝姿勢を識別する機械学習には，AdaBoostを多クラス化した SAMME(Zhu et al., 2009) を用いた. SAMME は, 単独では識別性能が低い弱識別器をいくつか組み合わせて, 識別性能の高い最終識別器を構成する.具体的には, 入力を $\boldsymbol{x}$, 識別対象のクラスを表すラベルを $k \in\{1, \cdots, K\}$, 弱識別器の番号を表すラベルを $m \in\{1, \cdots, M\}$, 弱識 別器を $h_{m}(\boldsymbol{x})$, 重みを $\alpha_{m}$ として, 最終識別器の出力を

$$
H(\boldsymbol{x})=\underset{k}{\arg \max } \sum_{m=1}^{M} \alpha_{m} \cdot I\left(h_{m}(\boldsymbol{x})=k\right)
$$

で求める.ただし， $I(\cdot)$ は，括弧内が真なら 1 , 偽なら 0 を出力する関数である. 学習により, 弱識別器 $h_{m}(\boldsymbol{x})$ の 
選択と重み $\alpha_{m}$ の決定を行なう。本稿では, 第 3 章に示寸センサの出力を入力 $\boldsymbol{x}$ とし, 図 6 に示す 4 種類の寝姿勢 と分類不可の 5 クラスを出力とした.

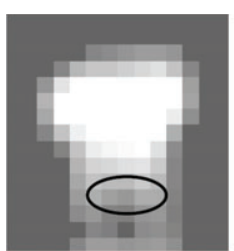

Supine posture

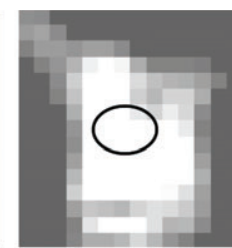

Prone posture

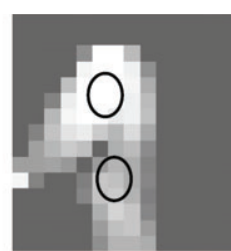

Right lateral posture Left lateral posture

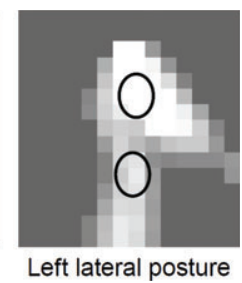

Fig. 2 Suitable locations for measurement of heartbeat. The circles show the suitable locations for different body postures. The suitable locations depend on not only the location but also the lying posture of the person on the sensor (Mukai, Matsuo et al., 2014).

\section{$2 \cdot 2$ 寝姿勢識別の成否と呼吸・心拍の信号強度との関係}

実際に一晚（約 7 時間 30 分）の計測を行い，寝姿勢識別の成否が計測される心拍の SN 比に与える影響を調查 した結果を図 3 に示寸. ベッドに敷いた SR センサの上で約 7 時間 30 分に渡って測定した体圧データを 1 分ごと の区間に分割し，向井らの手法 (2014) を用いて各区間の寝姿勢を識別する. その識別結果とビデオカメラで撮影 した映像から人が判断した寝姿勢の真值とを比較することで, 各区間を寝姿勢識別に成功した時間と失敗した時 間とに分ける.さらに, 各区間において, 寝姿勢の識別結果に応じた位置（図 2）の体圧の時系列データに FFT を 適用して心拍信号の SN 比を求める. その SN 比を, 寝姿勢識別に成功した区間と失敗した区間とで比較したのが 図 3 である. なお, SN 比とは信号と雑音の比の対数で表される信号強度であり, 高いほど心拍の計測に成功して いると言える. 図 3 より, 寝姿勢の識別に失敗すると心拍の SN 比が有意に低く, 計測に失敗する可能性が高いこ とが分かる.

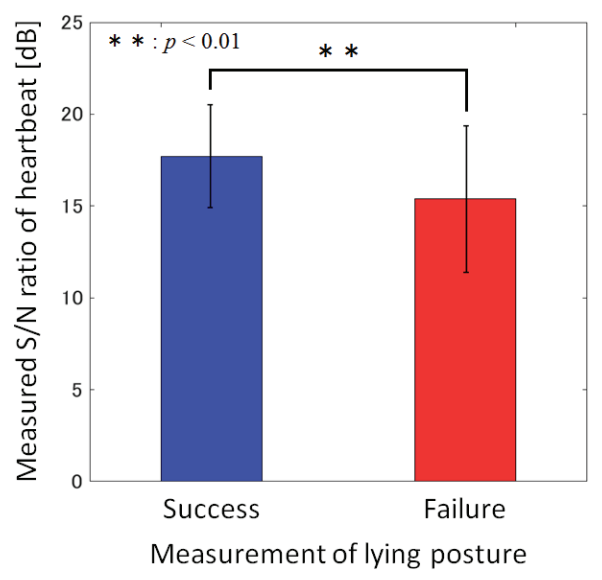

Fig. 3 Measured S/N ratios of heartbeat when recognition results of lying postures have ended in success or in failure. The recognition results of lying postures and the measured signal intensities of heartbeat have positive correlation.

呼吸は心拍に比べて圧力変動が大きいため, 体のどこかの位置の圧を測定すれば問題なく計測できることが 多い.しかし, 寝姿勢の識別に大きく失敗して圧力の測定位置が体の外に出てしまうと, 当然だが呼吸も計測でき ない. 図 4 に, その失敗例を示す. 実際は左横向きである寝姿勢を仰向けと誤識別したために, 圧力の測定位置が 体の外に出てしまい, 呼吸の計測に失敗している. 図 4 の右上に示された圧力の時系列データは, 変化する範囲 が非常に小さくノイズであることが分かる. そのため, 周波数解析を適用しても呼吸のピークが得られていない. 


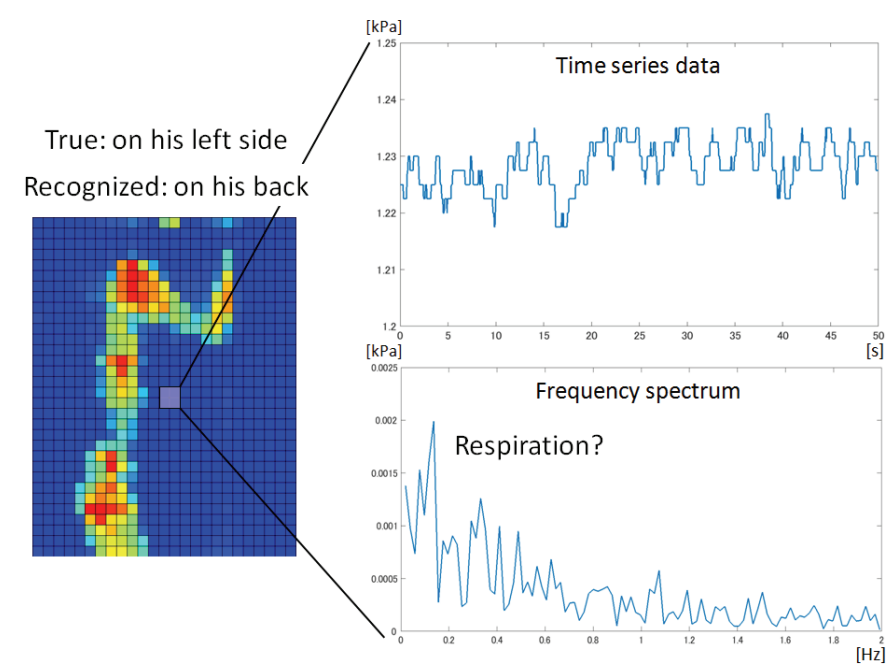

Fig. 4 Failure example of respiration measurement. We can not obtain respiration by means of using the time series data measured at cells without body pressure.

\section{$2 \cdot 3$ 呼吸と心拍の信号強度を用いた寝姿勢識別の改善}

第 $2 \cdot 2$ 節で述べたように, 寝姿勢識別に失敗すると, 呼吸と心拍の計測にも失敗しやすくなる，逆に考えると， 計測された呼吸と心拍の信号強度が強い場合は, 寝姿勢識別に成功している可能性が高い, そこで本稿では, 触 画像から得られる確信度に加えて, 呼吸と心拍の信号強度も用いることで, 寝姿勢の識別性能を改善寸る手法を 提案する. 具体的には, 触画像の時系列データ $\boldsymbol{x}$ から機械学習により得られる各寝姿勢の確信度 $p_{i}(\boldsymbol{x})$ に加えて, 各寝姿勢を仮定した場合に計測される呼吸の信号強度 $r_{i}(\boldsymbol{x})$ と心拍の信号強度 $h_{i}(\boldsymbol{x})$ も用いた確信度

$$
\widehat{p}_{i}(\boldsymbol{x})=\alpha \cdot r_{i}(\boldsymbol{x})+\beta \cdot h_{i}(\boldsymbol{x})+\gamma \cdot p_{i}(\boldsymbol{x})
$$

に基づいて寝姿勢を識別する. ただし， $\alpha, \beta, \gamma$ は重みであり， $\alpha+\beta+\gamma=1$ かつ $0 \leq \alpha, \beta, \gamma \leq 1$ とする. また, $i$ は寝姿勢番号であり, 識別する寝姿勢が $N$ 種類のとき, $\widehat{p_{1}}(\boldsymbol{x})$ から $\widehat{p_{N}}(\boldsymbol{x})$ までの確信度が得られる. 本稿では, それらが最大となる寝姿勢を識別結果とした. なお, 呼吸と心拍の信号強度である $r_{i}(\boldsymbol{x})$ と $h_{i}(\boldsymbol{x})$ としては, SN 比 や信号と雑音の比が考えられる。本稿における実験では，呼吸と心拍の SN 比をそれぞれ用いた。

\subsection{1 呼吸と心拍の SN 比}

本稿で呼吸と心拍の信号強度として用いた SN 比について説明する. 各寝姿勢を仮定し, それに応じた位置の体 圧の時系列デー夕に対する周波数解析の結果から, 呼吸の $\mathrm{SN}$ 比 $S N_{r i}$ と心拍の $\mathrm{SN}$ 比 $S N_{h i}$ を求める. それぞれの $\mathrm{SN}$ 比は,

$$
\begin{aligned}
& S N_{r i}=20 \log _{10} \frac{S_{r i}}{N_{i}}, \\
& S N_{h i}=20 \log _{10} \frac{S_{h i}}{N_{i}}
\end{aligned}
$$

と定義した．なお， $S_{r i}$ は呼吸信号， $S_{h i}$ は心拍信号であり， $N_{i}$ は雑音信号である. 呼吸の周波数帯域 $(0.1[\mathrm{~Hz}] \sim$ $0.4[\mathrm{~Hz}])$ と心拍の周波数帯域（0.8[Hz]～1.6[Hz]）における最大スペクトルを，それぞれ $S_{r i}$ と $S_{h i}$ とした.また， $N_{i}$ は全周波数帯域から呼吸信号帯域と心拍信号帯域と体動帯域を除いた残りの部分における信号の RMS とした. 呼吸信号帯域は， $S_{r i}$ をとる周波数 $f_{r i}$ および呼吸の 2 倍波をとる $2 f_{r i}$ と 3 倍波をとる $3 f_{r i}$ から $0.05[\mathrm{~Hz}]$ 以内の範 囲である. 心拍信号帯域は, $S_{h i}$ をとる周波数 $f_{h i}$ および心拍の 2 倍波をとる $2 f_{h i}$ から $0.05[\mathrm{~Hz}]$ 以内の範囲である. 予備実験の結果, 呼吸と心拍の信号のピーク幅がおよそ $0.1[\mathrm{~Hz}]$ だったため, ピークから $0.05[\mathrm{~Hz}]$ の範囲を信号 帯域に採用している. また，体動帯域は $0.0[\mathrm{~Hz}] \sim 0.1[\mathrm{~Hz}]$ の範囲とした. 


\section{3. 柔軟面状触覚センサ}

提案手法を実行するためには，ベッドに横になっている人の体圧を空間的にも圧力的にも高解像度で測定できる センサが必要である. 我々は, 面状触覚センサである SR センサを用いた. SR センサは配線を含めてすべてゴム 系の材料で作られている. そのため十分に柔らかく伸縮性があり, 違和感を覚えさせない測定が可能である. ま た，直接に触れなくても測定できるので，センサをシーツなどで覆っても問題ない．ゆえに， ベッドに敷いた SR センサを用いることで，非侵襲かつ無拘束に自然な睡眠に近い状態を測定できる.

SR センサは，2 枚の導電性ゴムシートの電極で，薄く柔軟な誘電層を挟んだ構造をしている（図 5)．ゴムシー トの黒色部分はカーボンフィラーを充填して作られた導電性ゴムから成る電極であり, 両側で直交するように配 置されている. 両側の電極の本数をそれぞれ $m$ 本と $n$ 本とすると, 両側の電極が交差するところごとに静電容量 センサができるので, 全体では $m \times n$ 個のセルが構成される. 電極の幅を細く寸れば空間的に高解像度に測定する ことができ，セルの面積を大きくすれば圧力的に高解像度な測定が実現できる.

圧力が加わると誘電層が変形して電極間距離が短くなるので, 該当部分の静電容量が増加寸る. センサコント ローラでそれぞれのセルの静電容量をスキャンすることで, 2 次元的な圧力パターンを検出することが可能となる. 具体的には, 各セルに正弦波状の電圧を印加し, 流れる電流からインピーダンスを求め, その值から静電容量值 を求めている. なお，スキャン時の等価回路はセルのコンデンサに配線抵抗が直列に接続されたものとなるので, センサコントローラでセルごとに異なる配線抵抗值の影響を排除している. このようなセンサ構成は古くから提 案されており，金属電極のセンサも市販されている (Cork, 2007) が，睡眠モニタリングシステムなどの介護福祉機 器への応用においては，伸縮性不足や高コストなどの課題が残っていた。 そこで，我々はゴム材料を用いた印刷 技術により，柔軟で安価な SR センサを開発した。このセンサは，住友理工（株）より「SRソフトビジョン」の 名称で販売されている.

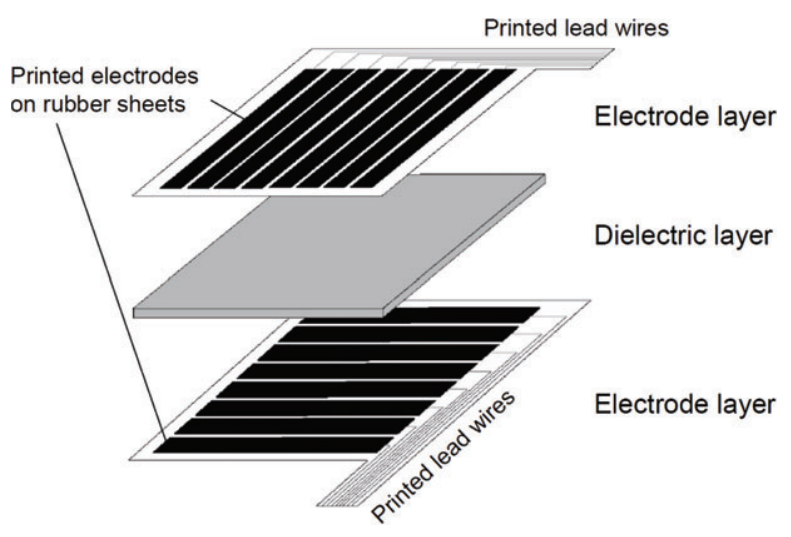

Fig. 5 Schematic structure of SR sensor.

本稿で使用した SR センサの仕様を表 1 に示す，この電極の幅であれば，寝姿勢を識別するのに十分な空間的解 像度で体圧を測定できる，一方，七ルの面積が小さくなると，それに伴って圧力の解像度は低くなる，このセン サでは，呼吸は圧力変動が大きいため問題なく計測できるが，心拍は圧力変動が小さいためそのままではノイズ によって読み取れない，そこで，心拍を計測するために，ノイズを抑制して圧力の解像度を上げる必要がある.

信号周期と比べて高速に多数回サンプリングを行い, それらの平均を用いることで SN 比を向上寸るオーバー サンプリングという手法がある.ノイズがランダムであれば， $N$ 回の測定值の平均を求めることで，ノイズ成分 の振幅を $1 / \sqrt{N}$ に低減することができる，本センサでは，オーバーサンプリングにより心拍を計測できるだけの SN 比を達成している. しかし, この手法をセンサのすべてのセルで行うと時間がかかりすぎるため, 呼吸と心拍 の計測に必要な測定周波数を確保できない.ゆえに, 高精度計測は一部のセルに限定する必要がある. 本稿で用 いるセンサは, 1 セル当たり約 $160[\mu \mathrm{s}]$ の測定時間が必要である. そこで，センサに搭載されたマイコンの計算能 力の制限により, 高精度計測を行うセルは 4 つとした。この 4 つのセルを高精度セルと呼ぶことにする. 高精度 セルが 4 つであれば $20[\mathrm{~Hz}]$ の測定周波数を実現できるため, 呼吸と心拍の計測が可能となる. 数が限られている 
ため, 高精度セルは心拍の計測に適したところに配置する必要がある. 本稿では, 寝姿勢の識別結果に応じて図 2 に示す位置に高精度セルを配置した. 第 4 章の実験において, 呼吸と心拍を計測するための FFT には, 高精度 セルで測定した体圧データを用いている，なお，本実験では 46 回の平均を求めることでオーバーサンプリングを 行った. 以前の研究から，これで心拍を計測可能なところまでノイズを抑制できることが判明している(向井他， 2014). また, 高精度セルの測定と並行して, 全 800 セルの測定も5[Hz] で行った. 800 セルの測定值から成る触 画像を用いて寝姿勢を識別する。

Table 1 Specifications of the SR sensor.

\begin{tabular}{c|c|c}
\multirow{2}{*}{ Number of cells } & \multicolumn{2}{|c}{800} \\
\cline { 2 - 3 } & Length & Width \\
\cline { 2 - 3 } & 32 & 25 \\
\hline Size of sensor sheet & $882[\mathrm{~mm}]$ & $686[\mathrm{~mm}]$ \\
\hline Size of a sensor cell & $14[\mathrm{~mm}]$ & $14[\mathrm{~mm}]$ \\
\hline Size of a gap between cells & $14[\mathrm{~mm}]$ & $14[\mathrm{~mm}]$ \\
\hline Thickness of sensor sheet & \multicolumn{2}{|c}{$3.5[\mathrm{~mm}]$} \\
\hline Sampling rate of all the 800 cells & \multicolumn{2}{|c}{$5[\mathrm{~Hz}]$} \\
\hline Sampling rate of the 4 precision cells & \multicolumn{2}{|c}{$20[\mathrm{~Hz}]$} \\
\hline
\end{tabular}

\section{4. 寝姿勢の識別実験}

\section{$4 \cdot 1$ 実験方法}

提案手法の有効性を評価するために，ベッドに敷いた SR センサの上に横になった人の寝姿勢を識別する実験を 行った. 識別対象は，仰向けとうつぶせと右横向きと左横向きの 4 種類とした。 その 4 種類の寝姿勢を図 6 に示 す.これら 4 種類の寝姿勢を各 10 回ずつ行い, 計 40 回分の体圧の時系列データを取得した. この 40 回分のデー タそれぞれについて，第 $2 \cdot 3$ 節で定義した確信度 $\widehat{p}_{i}(\boldsymbol{x})$ を求め，寝姿勢の識別を行う。

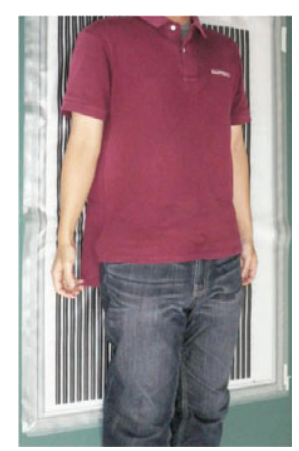

on his back

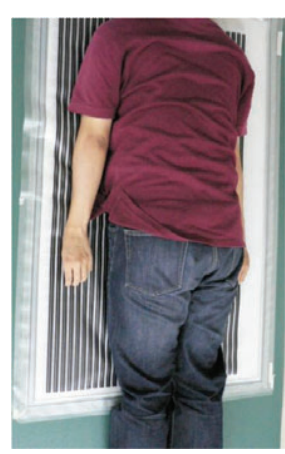

on his stomach

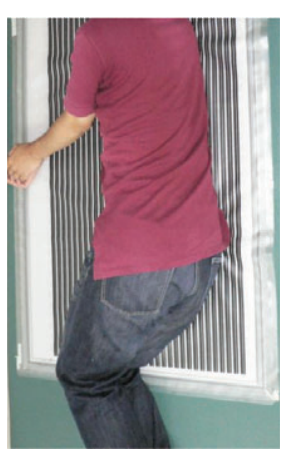

on his right side

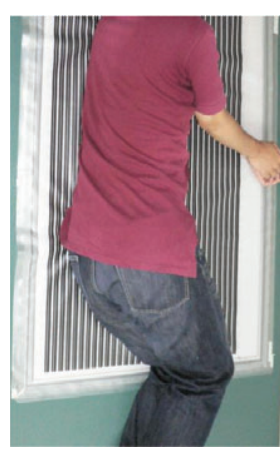

on his left side

Fig. 6 Photographs of the four postures.

まず，体圧データから向井らの手法 (2014) を用いて各寝姿勢の確信度 $p_{i}(\boldsymbol{x})$ を求める. FFT を行うためにはデー 夕数が 2 の累乗である必要があるので, 1 回分の体圧データは 51.2 秒間 $(51.2 \times 20[\mathrm{~Hz}]=1024)$ とした。被験者 は 51.2 秒間ずっと同じ寝姿勢を保つので，求められる確信度はほぼ一定となる。そのため， 51.2 秒間の平均值を $p_{i}(\boldsymbol{x})$ とした. 次に，4つの高精度セルを図 2 に示した各寝姿勢における心拍計測に適した位置にそれぞれ配置し， 測定された体圧の時系列データから呼吸と心拍の信号強度 $\left(r_{i}(\boldsymbol{x})\right.$ と $\left.h_{i}(\boldsymbol{x}), \quad i=1,2,3,4\right)$ を得る. 本稿では, 信号 
強度として SN 比を用いた. 最後に, これらから $\widehat{p}_{i}(\boldsymbol{x})$ を計算し, 寝姿勢の識別を行った. なお, 本研究は九州工 業大学の研究倫理委員会で承認されており，実験参加者からは書面でのインフォームドコンセントを得ている.

触画像による確信度 $p_{i}(\boldsymbol{x})$ のみを用いた寝姿勢識別が詋っていても, 真の寝姿勢における呼吸や心拍の信号強度 が他より強ければ，適切な重みを設定することにより， $\widehat{p}_{i}(\boldsymbol{x})$ に基づく最終的な識別結果は正しく修正できる. 提 案手法の性能を評価するために，以下の 3 つの実験を行った。 それぞれの実験の概要について説明する.

\section{同じ試行に対する寝姿勢の識別実験}

34 歳の男性を被験者として 40 回分のデータを取得し, そのデータセットを A 1 とする. データセットA 1 に おいて, 重み $(\alpha, \beta, \gamma)$ を様々な值にしたときの識別率を調査した.また, 4 種類の寝姿勢の混同行列につい ても調べた.

\section{同じ被験者の異なる試行に対する寝姿勢の識別実験}

データセット A 1 と同じ被験者で新たに 40 回の計測を行い, 得られたデータセットを A2 とする. A 1 で識別 率が最大となる重みを $\mathrm{A} 2$ に適用し, 識別率を求めた。 その求めた識別率と $\mathrm{A} 2$ の触画像のみを用いた識別率 $((\alpha, \beta, \gamma)=(0,0,1))$ を比較した. また, A1 と A2 を逆にして同様の実験を行った. 以上の実験により, 異な る試行に対する提案手法の汎用性を調査した.

\section{異なる被験者に対する寝姿勢の識別実験}

データセットA1 とは異なる被験者で同様の計測を行い，得られたデータセットを B1 とする，なお，被験者 は22 歳の男性である. 前述の実験と同様に, 異なる被験者に対する提案手法の汎用性を調査した。

\section{$4 \cdot 2$ 実験結果と考察}

\subsection{1 同じ試行に対する寝姿勢の識別実験}

重みを 0 から 1 まで 0.1 刻みで変化させたときの識別率を図 7 に示す. 横軸は重み $\alpha$, 縦軸は重み $\beta$ であり, 色 はその四角形の左下の座標が示す重みに対応する識別率である. $\alpha+\beta+\gamma=1$ かつ $0 \leq \alpha, \beta, \gamma \leq 1$ という条件よ り，それぞれの重みがとる值は $\alpha=0,0.1, \cdots, 1, \beta=0,0.1, \cdots, 1-\alpha, \gamma=1-\alpha-\beta$ となる. $\alpha$ と $\beta$ の值が決ま ると $\gamma$ の值はひとつに定まるので, 重み $\gamma$ につては図 7 に表示していない.

図 7 より, $(\alpha, \beta, \gamma)=(0.6,0.1,0.3)$ とした場合およびその周辺で, 識別率が $82.5 \%$ と最も高くなることが分かる. 詳しく述べると， $(\alpha, \beta, \gamma)=(0.5,0.1,0.4),(0.5,0.2,0.3),(0.6,0,0.4),(0.6,0.1,0.3),(0.7,0,0.3)$ の 5 組の重みで最高值を取 る. 一方, 触画像のみを用いた従来手法は, $(\alpha, \beta, \gamma)=(0,0,1)$ とした場合であり, その識別率は図 7 の原点に示さ れている 72.5\%である. 従来手法よりも提案手法で重みを $(\alpha, \beta, \gamma)=(0.6,0.1,0.3)$ などとした場合の方が，識別率 が 10.0\%向上している.

さらに, 40 回分のデータであるデータセットA1 から得られたパラメータの平均值と標準偏差を表 2 に示す. こ れは重みを $(\alpha, \beta, \gamma)=(0.6,0.1,0.3)$ とした場合の $p_{i}(\boldsymbol{x}), r_{i}(\boldsymbol{x}), h_{i}(\boldsymbol{x}), \widehat{p}_{i}(\boldsymbol{x})$ の值であり, 上の列に真の寝姿勢につ いてのパラメータを，下の列に偽の寝姿勢についてのパラメータをそれぞれ示している．なお，偽の寝姿勢とは， 真でない 3 つの寝姿勢のうちの值が最大であるものとした. どのパラメータもすべて寝姿勢が真であるものの方 が大きく, 識別に用いるのに適切であることが分かる. また, $p_{i}(\boldsymbol{x})$ と $\widehat{p}_{i}(\boldsymbol{x})$ について, 寝姿勢が真であるものと偽 であるものの比を第 7 列と第 8 列にそれぞれ示した。この比が大きいほど, 真の寝姿勢の確信度がそれ以外の寝姿 勢の確信度に対して大きく, 安定して識別を行うことができる。この 2 つの比に差があるかどうかについて，有 意水準を 0.05 として対応のある $\mathrm{t}$ 検定を行った。帰無仮説は, $「 p_{i}(\boldsymbol{x})$ と $\widehat{p}_{i}(\boldsymbol{x})$ で比に差はない」である.また，自 由度は 39 である.すると, $\mathrm{t}$ 值 $t=-3.27$, 有意確率 $p=2.3 \times 10^{-3}$ となり, 有意に差があることが分かった。こ れより, 触画像から得られる確信度に加えて, 呼吸と心拍の信号強度も適切に用いることで, 寝姿勢識別を改善 できることが確かめられた。

また，提案手法と従来手法の混同行列を表 3 と表 4 にそれぞれ示す。これらの表から，全体の識別率だけでな く各寝姿勢の識別性能も, 呼吸と心拍の信号強度を用いることで向上していることが分かる. 以上より, 提案手 法の有効性を確認できた. 


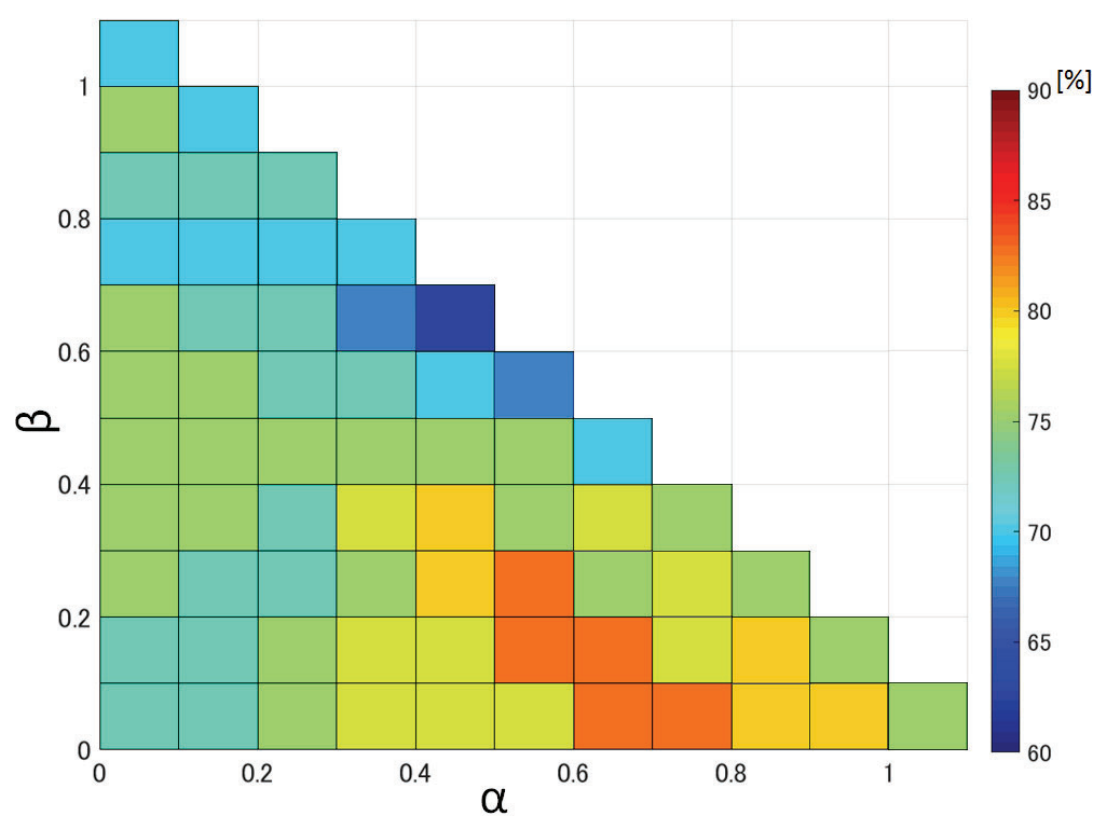

Fig. 7 Recognition rates of the lying postures (Dataset A1). Recognition of lying postures is improved by means of using a measured signal intensity of respiration and heartbeat. For example, the recognition rate of $(\alpha, \beta, \gamma)=(0.6,0.1,0.3)$ is higher than that of $(\alpha, \beta, \gamma)=(0,0,1)$.

Table 2 Parameters of Dataset A1 with $(\alpha, \beta, \gamma)=(0.6,0.1,0.3): p_{i}(\boldsymbol{x}), r_{i}(\boldsymbol{x}), h_{i}(\boldsymbol{x}), \widehat{p}_{i}(\boldsymbol{x}), p_{\mathrm{T}}(\boldsymbol{x}) / p_{\mathrm{F}}(\boldsymbol{x})$, and $\widehat{p_{\mathrm{T}}}(\boldsymbol{x}) / \widehat{p_{\mathrm{F}}}(\boldsymbol{x})$. Recognition performance using $\widehat{p}_{i}(\boldsymbol{x})$ is improved than that using $p_{i}(\boldsymbol{x})$.

\begin{tabular}{c|c|c|c|c|c|c|c}
\hline Dataset and Weights & Lying posture & $p_{i}(\boldsymbol{x})$ & $r_{i}(\boldsymbol{x})$ & $h_{i}(\boldsymbol{x})$ & $\widehat{p}_{i}(\boldsymbol{x})$ & $p_{\mathrm{T}}(\boldsymbol{x}) / p_{\mathrm{F}}(\boldsymbol{x})$ & $\widehat{p_{\mathrm{T}}}(\boldsymbol{x}) / \widehat{p_{\mathrm{F}}}(\boldsymbol{x})$ \\
\hline Dataset A1, & True & $50.1 \pm 15.7$ & $33.1 \pm 4.4$ & $17.1 \pm 5.3$ & $40.2 \pm 5.8$ & & \multirow{2}{*}{$2.09 \pm 1.30$} \\
\cline { 2 - 6 }$(\alpha, \beta, \gamma)=(0.6,0.1,0.3)$ & False & $29.7 \pm 19.0$ & $20.5 \pm 12.3$ & $8.5 \pm 6.1$ & $19.8 \pm 11.6$ & & \\
\hline
\end{tabular}

Table 3 Confusion matrix of lying posture recognition $((\alpha, \beta, \gamma)=(0.6,0.1,0.3)$, Dataset A1). Recognition of each lying posture is improved by means of using a measured signal intensity of respiration and heartbeat.

\begin{tabular}{|c|c|c|c|c|}
\hline True Recognized & on his back & on his stomach & on his right & on his left \\
\hline on his back & 10 & 0 & 0 & 0 \\
\hline on his stomach & 0 & 10 & 0 & 0 \\
\hline on his right & 1 & 1 & 6 & 2 \\
\hline on his left & 1 & 1 & 1 & 7 \\
\hline
\end{tabular}

\section{4·2·2 同じ被験者の異なる試行に対する寝姿勢の識別実験}

提案手法の汎用性を調査するため, 第 $4 \cdot 2 \cdot 1$ 節と同様の実験を同じ被験者に異なる日時で行 い，2つのデータを比較した。前節のデータセットを $\mathrm{A} 1$, 本節のデータセットを $\mathrm{A} 2$ とする. まず，第 $4 \cdot 2 \cdot 1$ 節と同様に，データセット $\mathrm{A} 2$ の識別率を求めた結果を図 8 に示す. $(\alpha, \beta, \gamma)=$ $(0,0.8,0.2),(0.1,0.5,0.4),(0.1,0.6,0.3),(0.1,0.7,0.2),(0.2,0.6,0.2),(0.5,0.1,0.4),(0.5,0.2,0.3),(0.6,0,0.4),(0.6,0.1,0.3) \quad の 9$ 組の重みで識別率が最も高くなっている。これより，提案手法で重みを適切に決定すれば，データセットA2 でも 
Table 4 Confusion matrix of lying posture recognition $((\alpha, \beta, \gamma)=(0,0,1)$, Dataset A1). Recognition of each lying posture without using respiration and heartbeat is low.

\begin{tabular}{|c|c|c|c|c|}
\hline True & on his back & on his stomach & on his right & on his left \\
\hline on his back & 9 & 0 & 1 & 0 \\
\hline on his stomach & 0 & 8 & 0 & 2 \\
\hline on his right & 2 & 1 & 5 & 2 \\
\hline on his left & 1 & 1 & 1 & 7 \\
\hline
\end{tabular}

従来手法より識別率を向上できることが分かる.

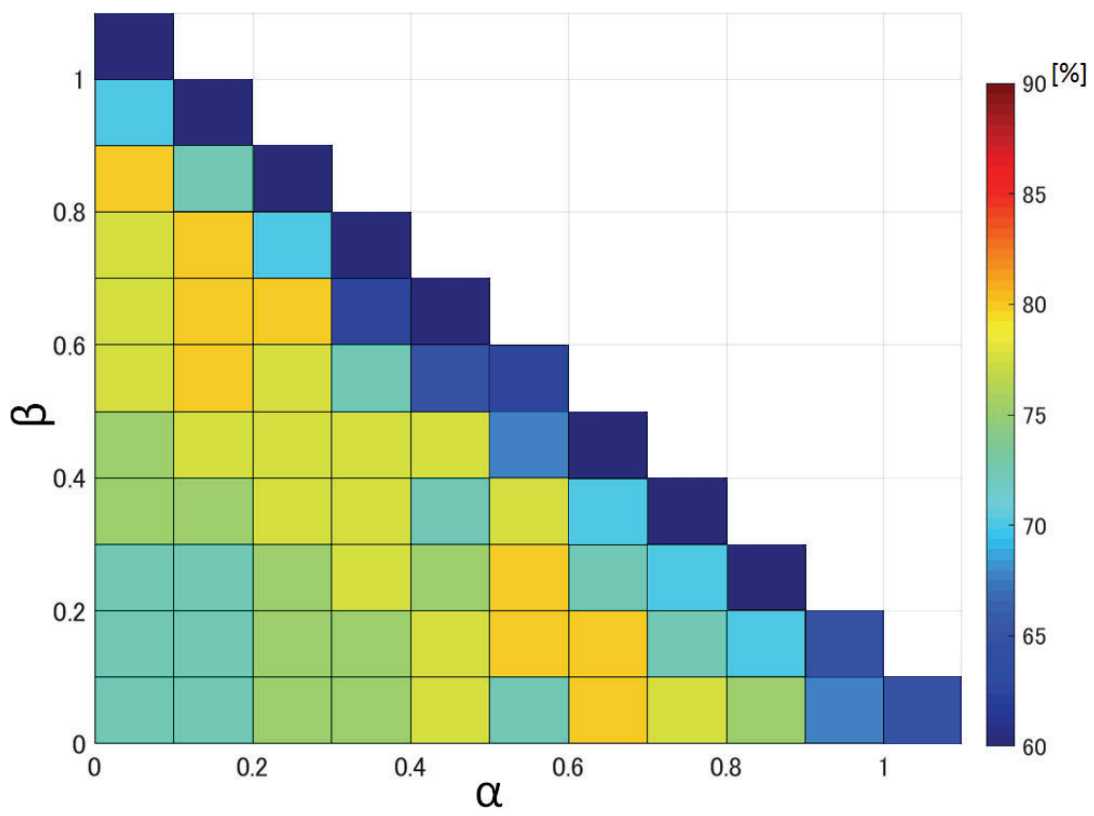

Fig. 8 Recognition rates of the lying postures (Dataset A2). Recognition of lying postures is improved by means of using a measured signal intensity of respiration and heartbeat. For example, the recognition rate of $(\alpha, \beta, \gamma)=(0.1,0.6,0.3)$ is higher than that of $(\alpha, \beta, \gamma)=(0,0,1)$.

また，片方のデータセットから求めた重みを用いて，もう片方のデータセットを識別する実験を行った。その 結果を表 5 に示す．第 1 列のデータセットにおいて識別率が最大となる重みを求め, それを用いて第 2 列のデー タセットを識別した結果が，第 3 列の識別率である。識別率が最大となる重みが複数ある場合は，それらを用い た第 2 列のデータセットの識別率をすべて求め, その平均值を第 3 列に表示している. つまり, 79.5\%は 5 組の重 みによる平均值であり， $76.9 \%$ は 9 組の重みを用いた平均值である. なお，第 4 列には $(\alpha, \beta, \gamma)=(0,0,1)$ として， 従来手法により第 2 列のデータセットを識別した結果を示す.

さらに, 得られたパラメータの平均值と標準偏差を表 6 に示す. 前述のように適切な重みが複数あるため, それ らを用いたときのパラメータをすべて計算し，その平均值を用いた。それ以外は表 2 と同様である. 第 3 列から 第 6 列までのパラメータはすべて寝姿勢が真であるものの方が大きく，識別に用いるのに適切であることが分か る. また, 第 7 列と第 8 列の 2 つの比について, 第 $4 \cdot 2 \cdot 1$ 節と同様に対応あり $\mathrm{t}$ 検定を行った. A 1 から求めた重 みを用いて A2 を識別した 40 のデータと, データセットを逆にした 40 のデータを合わせて $\mathrm{t}$ 検定を行ったので， 
Table 5 Recognition rates [\%] of the lying postures (Dataset A1 \& A2): The weights $(\alpha, \beta, \gamma)$ are determined from the 1 st column dataset, and then the 2 nd column dataset are recognised by means of using them. Recognition performance is improved by means of using the weights determined from another trial dataset.

\begin{tabular}{c|c|c|c}
\hline $\begin{array}{c}\text { Weights }(\alpha, \beta, \gamma) \text { are } \\
\text { determined from }\end{array}$ & $\begin{array}{c}\text { Evaluation } \\
\text { dataset }\end{array}$ & $\begin{array}{c}\text { Proposed } \\
\text { method }\end{array}$ & $\begin{array}{c}\text { Conventional } \\
\text { method }\end{array}$ \\
\hline Dataset A1 & A2 & 79.5 & 72.5 \\
\hline Dataset A2 & A1 & 76.9 & 72.5 \\
\hline \multicolumn{2}{c|}{ Average } & 78.2 & 72.5 \\
\hline
\end{tabular}

自由度は 79 である. すると, $\mathrm{t}$ 值 $t=-2.02$, 有意確率 $p=4.7 \times 10^{-2}$ となり，有意に差があることが分かった.

これらの結果より，重みを決めるデータと識別するデータが異なる場合でも，提案手法を用いれば識別性能を 改善できることが分かる。これにより，同じ被験者の異なる試行に対する提案手法の汎用性を確認することがで きた。

Table 6 Parameters of Dataset A2 with the 5 sets of the weights determined from Dataset A1, and Dataset A1 with the 9 sets of the weights determined from Dataset A2: $p_{i}(\boldsymbol{x}), r_{i}(\boldsymbol{x}), h_{i}(\boldsymbol{x}), \widehat{p}_{i}(\boldsymbol{x}), p_{\mathrm{T}}(\boldsymbol{x}) / p_{\mathrm{F}}(\boldsymbol{x})$, and $\widehat{p_{\mathrm{T}}}(\boldsymbol{x}) / \widehat{p_{\mathrm{F}}}(\boldsymbol{x})$. Recognition performance is improved by means of using $\widehat{p}_{i}(\boldsymbol{x})$ calculated by the weights determined from another trial dataset.

\begin{tabular}{c|c|c|c|c|c|c|c}
\hline Dataset and Weights & Lying posture & $p_{i}(\boldsymbol{x})$ & $r_{i}(\boldsymbol{x})$ & $h_{i}(\boldsymbol{x})$ & $\widehat{p}_{i}(\boldsymbol{x})$ & $p_{\mathrm{T}}(\boldsymbol{x}) / p_{\mathrm{F}}(\boldsymbol{x})$ & $\widehat{p_{\mathrm{T}}}(\boldsymbol{x}) / \widehat{p_{\mathrm{F}}}(\boldsymbol{x})$ \\
\hline \multirow{2}{*}{ Dataset A2, } & True & $49.3 \pm 14.1$ & $28.9 \pm 4.3$ & $11.4 \pm 2.3$ & $37.9 \pm 4.5$ & \multirow{3}{*}{$1.93 \pm 1.26$} & \multirow{2}{*}{$2.11 \pm 0.90$} \\
\cline { 2 - 6 } 5 sets of weights from A1 & False & $32.5 \pm 20.7$ & $18.8 \pm 9.6$ & $7.3 \pm 4.0$ & $20.3 \pm 10.6$ & & \\
\hline Dataset A1, & True & $50.1 \pm 15.7$ & $33.1 \pm 4.4$ & $17.1 \pm 5.3$ & $35.0 \pm 5.6$ & \multirow{2}{*}{$2.09 \pm 1.30$} & \multirow{2}{*}{$2.23 \pm 0.83$} \\
\cline { 2 - 6 } 9 sets of weights from A2 & False & $29.7 \pm 19.0$ & $20.5 \pm 12.3$ & $8.5 \pm 6.1$ & $16.6 \pm 9.8$ & & \\
\hline
\end{tabular}

\section{$4 \cdot 2 \cdot 3$ 異なる被験者に対する寝姿勢の識別実験}

第 4.2.2 節と同様の実験を異なる被験者で行い, 提案手法の汎用性を調査した. 本節のデータセットを B 1 とする. まず, データセット B1 の識別率を求めた結果を図 9 に示す. $(\alpha, \beta, \gamma)=(0,0,1),(0,0.1,0.9),(0.1,0,0.9),(0.2,0,0.8)$, $(0.3,0,0.7),(0.4,0.3,0.3),(0.6,0,0.4),(0.7,0,0.3)$ の 8 組の重みで識別率が最も高い. 従来手法による識別率が高いた め, 提案手法を用いて識別率を向上させることはできていないが，重みを適切に決定すれば，従来手法と同等の 性能で寝姿勢を識別できることが分かる.

また，A1 と B1 のデータセットを用いて，異なる被験者に対する汎用性を調べた。その結果を表 7 に示す。デー タセット B1 では触画像のみを用いた従来手法の識別率が高いので, B1 を評価データにしたときの識別率は従来 手法が提案手法を上回っている. しかし, 第 4 行に示す識別率の平均值は, 提案手法と従来手法でほぼ同等の值 になっている.

Table 7 Recognition rates [\%] of the lying postures (Dataset A1 \& B1): The weights $(\alpha, \beta, \gamma)$ are determined from the 1 st column dataset, and then the 2 nd column dataset are recognised by means of using them. Recognition performance using the weights determined from another person dataset is about the same as that of the conventional method.

\begin{tabular}{c|c|c|c}
\hline $\begin{array}{c}\text { Weights }(\alpha, \beta, \gamma) \text { are } \\
\text { determined from }\end{array}$ & $\begin{array}{c}\text { Evaluation } \\
\text { dataset }\end{array}$ & $\begin{array}{c}\text { Proposed } \\
\text { method }\end{array}$ & $\begin{array}{c}\text { Conventional } \\
\text { method }\end{array}$ \\
\hline Dataset A1 & B1 & 76.0 & 77.5 \\
\hline Dataset B1 & A1 & 76.9 & 72.5 \\
\hline \multicolumn{2}{c|}{ Average } & 76.4 & 75.0 \\
\hline
\end{tabular}

さらに，前節と同様に得られたパラメータの平均值と標準偏差を表 8 に示す. 4 つのパラメータはすべて寝姿勢 が真であるものの方が大きく, 識別に用いるのに適切であることが分かる．また， 2 つの比についての対応あり $\mathrm{t}$ 


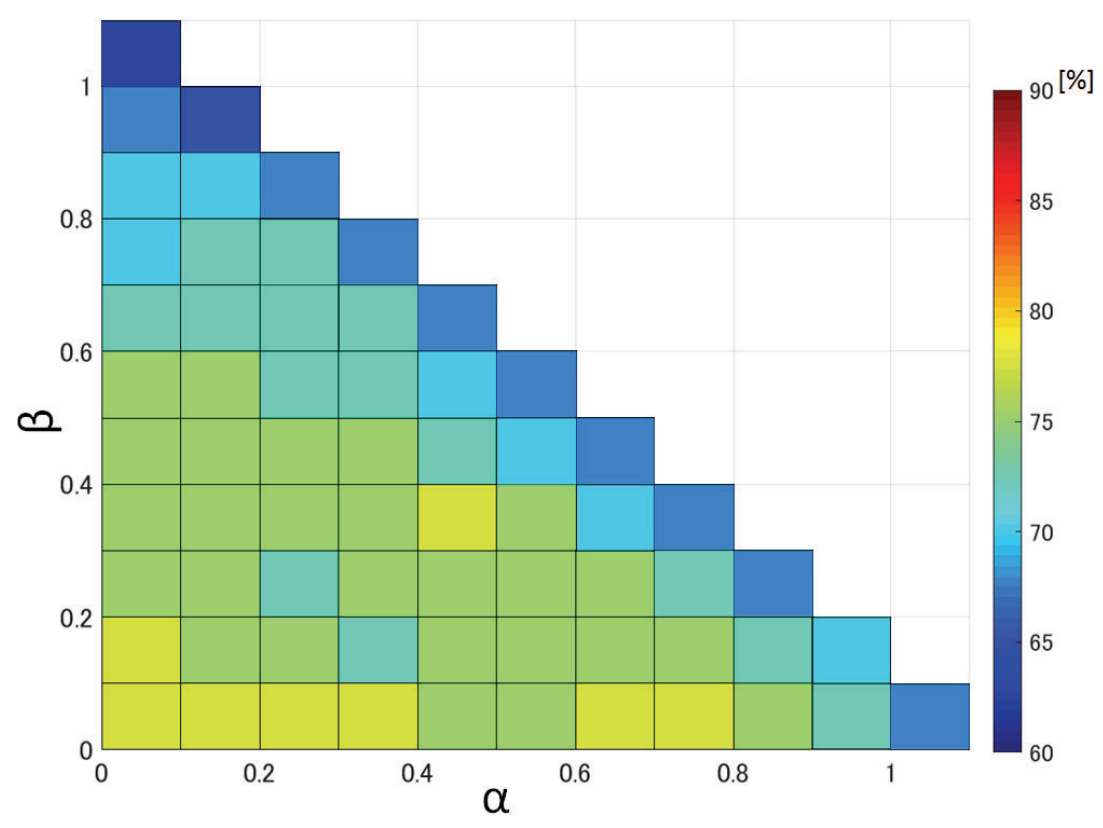

Fig. 9 Recognition rates of the lying postures (Dataset B1). Recognition of lying postures using a measured signal intensity of respiration and heartbeat has the same performance as that of the conventional method. For example, the recognition rate of $(\alpha, \beta, \gamma)=(0.4,0.3,0.3)$ is equal to that of $(\alpha, \beta, \gamma)=(0,0,1)$.

検定も前節と同様に行った。自由度は 79 である. すると, $\mathrm{t}$ 值 $t=-1.54$, 有意確率 $p=1.3 \times 10^{-1}$ となり, 差が あるとは言えないことが分かった。

これらの結果より，重みを決めるデータと識別するデータで被験者が異なると，提案手法と従来手法はほぼ同 じ識別性能を示すことが確認できた．各被験者に対する最適な重みを決定するのが今後の課題である.

Table 8 Parameters of Dataset B1 with the 5 sets of the weights determined from Dataset A1, and Dataset A1 with the 8 sets of the weights determined from Dataset B1: $p_{i}(\boldsymbol{x}), r_{i}(\boldsymbol{x}), h_{i}(\boldsymbol{x}), \widehat{p}_{i}(\boldsymbol{x}), p_{\mathrm{T}}(\boldsymbol{x}) / p_{\mathrm{F}}(\boldsymbol{x})$, and $\widehat{p_{\mathrm{T}}}(\boldsymbol{x}) / \widehat{p_{\mathrm{F}}}(\boldsymbol{x})$. Recognition performance using $\widehat{p}_{i}(\boldsymbol{x})$ determined from another person dataset is about the same as that of the conventional method.

\begin{tabular}{c|c|c|c|c|c|c|c}
\hline Dataset and Weights & Lying posture & $p_{i}(\boldsymbol{x})$ & $r_{i}(\boldsymbol{x})$ & $h_{i}(\boldsymbol{x})$ & $\widehat{p}_{i}(\boldsymbol{x})$ & $p_{\mathrm{T}}(\boldsymbol{x}) / p_{\mathrm{F}}(\boldsymbol{x})$ & $\widehat{p_{\mathrm{T}}}(\boldsymbol{x}) / \widehat{p_{\mathrm{F}}}(\boldsymbol{x})$ \\
\hline Dataset B1, & True & $39.4 \pm 17.6$ & $26.0 \pm 9.6$ & $13.2 \pm 6.8$ & $32.5 \pm 12.1$ & \multirow{3}{*}{$2.49 \pm 1.89$} & \multirow{2}{*}{$2.43 \pm 1.39$} \\
\cline { 2 - 7 } 5 sets of weights from A1 & False & $17.7 \pm 20.7$ & $10.0 \pm 11.7$ & $4.0 \pm 4.8$ & $10.9 \pm 12.5$ & & \\
\hline Dataset A1, & True & $50.1 \pm 15.7$ & $33.1 \pm 4.4$ & $17.1 \pm 5.3$ & $47.9 \pm 11.4$ & \multirow{2}{*}{$2.09 \pm 1.30$} & $2.39 \pm 1.18$ \\
\cline { 2 - 6 } 8 sets of weights from B1 & False & $29.7 \pm 19.0$ & $20.5 \pm 12.3$ & $8.5 \pm 6.1$ & $23.4 \pm 14.2$ & & \\
\hline
\end{tabular}

\section{5. 結 論}

計測された呼吸と心拍の信号強度を利用して寝姿勢の識別性能を改善する手法を提案した。実データを用いた実 験を行い，触画像から得られる確信度に加えて，呼吸と心拍の信号強度を用いることで寝姿勢の識別性能を向上で きることを示した。また，同じ被験者の別試行や異なる被験者のデータを用いて，提案手法の汎用性を確認した。

今後の課題としては，以下を考えている. 
- 被験者の人数や試行回数を増やして, 呼吸と心拍の信号強度をどれくらい重視すべきかを決定したい. つま り，重み $\alpha, \beta, \gamma$ 普遍的な值を決めることが今後の課題である．最適な重みの值には，体格や性別に基づく 個人差があることも考えられるため, それについても調査を行いたい.

・本稿では呼吸と心拍の信号強度として SN 比をそのまま用いたが，他の指標の方が寝姿勢の識別性能の向上に 適していることも考えられる。よって，SN 比以外を信号強度とした実験を行う予定である.

・寝姿勢が異なっても心拍計測に適した位置が同じセルとなった場合は，提案手法では識別性能を改善できな い，例えば，右横向きと左横向きで体の位置が同じである場合や，仰向けとうつぶせで体が上下にずれた場 合などは，同じセルが選ばれてしまう可能性がある，そこで，寝姿勢ごとに複数の位置に高精度セルを配置 するように手法を改善したい。最も心拍計測に適した位置の 1 セルだけでなく，異なる位置に配置した複数 セルで計測した呼吸と心拍の信号強度を用いることで，この問題を解決できると考えている.

文献

Alihanka, J., Vaahtoranta, K. and Saarikivi, I., A new method for long-term monitoring of the ballistocardiogram, heart rate, and respiration, American Journal of Physiology - Regulatory, Integrative and Comparative Physiology, Vol. 240, No. 5 (1981), R384-392.

Beattie, Z. T., Hagen, C. C. and Hayes, T. L., Classification of lying position using load cells under the bed, Proceedings of the 33rd Annual International Conference of the IEEE Engineering in Medicine and Biology Society (2011), pp. 474-477.

Cork, R., XSENSOR technology: a pressure imaging overview, Sensor Review, Vol. 27, No. 1 (2007), pp. 24-28.

Deguchi, A. and Hagiwara, H., Evaluation of heart rate variability and respiratory variability during sleep using a lorenz plot, Journal of Sleep and Biological Rhythms, Vol. 9, No. 4 (2011), p. 366.

Freund, Y. and Schapire, R., A decision-theoretic generalization of on-line learning and an application to boosting, Journal of Computer and System Science, Vol. 55 (1997), pp. 119-139.

Guo, S., Kato, Y., Ito, H. and Mukai, T., Development of rubber-based flexible sensor sheet for care-related apparatus, Sumitomo Electric Industries Technical Review, No. 75 (2012), pp. 125-131.

Harper, R. M., Schechtman, V. L. and Kluge, K. A., Machine classification of infant sleep state using cardiorespiratory measures, Electroencephalography and Clinical Neurophysiology, Vol. 67, No. 4 (1987), pp. 379-387.

日本睡眠学会, 睡眠学ハンドブック, 朝倉書店 (1999).

日本睡眠学会, 臨床睡眠検査マニュアル 改訂版, ライフ・サイエンス (2015).

Kambayashi, Y. and Hagiwara, H., Estimating sleep cycle using body movement density, Proceedings of the 20125 th International Conference on Biomedical Engineering and Informatics (2012), pp. 1029-1033.

Kurihara, Y. and Watanabe, K., Development of unconstrained heartbeat and respiration measurement system with pneumatic flow, IEEE Transactions on Biomedical Circuits and Systems, Vol. 6, No. 6 (2012a), pp. 596-604.

Kurihara, Y. and Watanabe, K., Sleep-stage decision algorithm by using heartbeat and body-movement signals, IEEE Transactions on Systems, Man, and Cybernetics, Part A, Vol. 42, No. 6 (2012b), pp. 1450-1459.

松尾一矢, 向井利春, 加藤陽, 郭士傑, 柔軟面状触覚センサを用いた呼吸と心拍の無拘束計測, 日本機械学会論文集, Vol. 81, No. 826 (2015), DOI: 10.1299/transjsme.14-00642.

経済産業省，厚生労働省，ロボット技術の介護利用における重点分野 (2012)， online，available from $<\mathrm{http}: / /$ robotcare.jp/>, (参照日 2018 年 3 月 1 日).

厚生労働省, 医療・介護に係る長期推計 (2011), online, available from < http://www.cas.go.jp/jp/seisaku/syakaihosyou /syutyukento/dai10/siryou1-2.pdf>, (参照日 2018 年 3 月 1 日).

森屋彰久, 鈴木玩治, 大内一成, 亀山研一, 脈波情報を用いた睡眠状態推定とその応用, ヒューマンインタフェース学 会論文誌, Vol. 10, No. 2 (2008), pp. 207-214.

向井利春, 松尾一矢, 加藤陽, 清水厚輝, 郭士傑, ベッド上の触覚センサによる姿勢・呼吸・心拍の無拘束測定, 日本 機械学会論文集, Vol. 80, No. 815 (2014), DOI: 10.1299/transjsme.2014bms0215.

国立社会保障 -人口問題研究所, 日本の将来推計人口 -平成 23(2011) 年～平成 72(2060) 年- (2012), online, available 
from <http://www.ipss.go.jp/syoushika/tohkei/newest04/sh2401top.html>, (参照日 2018 年 3 月 1 日).

野田明子, 古池保雄, 終夜睡眠ポリグラフィ, 生体医工学: 日本エム・イー学会誌, Vol. 46, No. 2 (2008), pp. $134-143$.

Okada, S., Ohno, Y., Goyahan, Kato-Nishimura, K., Mohri, I. and Taniike, M., Examination of non-restrictive and non-invasive sleep evaluation technique for children using difference images, Proceedings of the 30th Annual International Conference of the IEEE Engineering in Medicine and Biology Society (2008), pp. 2483-2487.

Otsuka, K., Ichimaru, Y., Yanaga, T. and Sato, Y., Studies of arrhythmias by 24-hour polygraphic recordings: relationship between atrioventricular block and sleep states, American Heart Journal, Vol. 105, No. 6 (1983), pp. 934-940.

Rechtschaffen, A. and Kales, A., A manual of standardized terminology, techniques and scoring system for sleep stages of human subjects, Bethesda, Md.: U. S. Dept. of Health, Education, and Welfare, Public Health Services-National Institutes of Health, National Institute of Neurological Diseases and Blindness, Neurological Information Network (1968).

Salmi, T. and Leinonen, L., Automatic analysis of sleep records with static charge sensitive bed, Electroencephalography and Clinical Neurophysiology, Vol. 64, No. 1 (1986), pp. 84-87.

総務省統計局, 平成 22 年国勢調査 (2011), online, available from $<$ http://www.stat.go.jp/data/kokusei/2010/index.htm>, (参照日 2018 年 3 月 1 日).

Watanabe, K., Watanabe, T., Watanabe, H., Ando, H., Ishikawa, T. and Kobayashi, K., Noninvasive measurement of heartbeat, respiration, snoring and body movements of a subject in bed via a pneumatic method, IEEE Transactions on Biomedical Engineering, Vol. 52, No. 12 (2005), pp. 2100-2107.

渡邊崇士, 渡辺嘉二郎, 無拘束エアマットレス型生体センサによる睡眠段階の推定 -心拍数変動と睡眠段階-, 計測自 動制御学会論文集, Vol. 37, No. 9 (2001), pp. 821-828.

Watanabe, T. and Watanabe, K., Noncontact method for sleep stage estimation, IEEE Transactions on Biomedical Engineering, Vol. 51, No. 10 (2004), pp. 1735-1748.

Zhu, J., Zou, H., Rosset, S. and Hastie, T., Multi-class AdaBoost, Statistics and its Interface, Vol. 2 (2009), pp. $349-360$.

\section{References}

Alihanka, J., Vaahtoranta, K. and Saarikivi, I., A new method for long-term monitoring of the ballistocardiogram, heart rate, and respiration, American Journal of Physiology - Regulatory, Integrative and Comparative Physiology, Vol. 240, No. 5 (1981), R384-392.

Beattie, Z. T., Hagen, C. C. and Hayes, T. L., Classification of lying position using load cells under the bed, Proceedings of the 33rd Annual International Conference of the IEEE Engineering in Medicine and Biology Society (2011), pp. 474-477.

Cork, R., XSENSOR technology: a pressure imaging overview, Sensor Review, Vol. 27, No. 1 (2007), pp. 24-28.

Deguchi, A. and Hagiwara, H., Evaluation of heart rate variability and respiratory variability during sleep using a lorenz plot, Journal of Sleep and Biological Rhythms, Vol. 9, No. 4 (2011), p. 366.

Freund, Y. and Schapire, R., A decision-theoretic generalization of on-line learning and an application to boosting, Journal of Computer and System Science, Vol. 55 (1997), pp. 119-139.

Guo, S., Kato, Y., Ito, H. and Mukai, T., Development of rubber-based flexible sensor sheet for care-related apparatus, Sumitomo Electric Industries Technical Review, No. 75 (2012), pp. 125-131.

Harper, R. M., Schechtman, V. L. and Kluge, K. A., Machine classification of infant sleep state using cardiorespiratory measures, Electroencephalography and Clinical Neurophysiology, Vol. 67, No. 4 (1987), pp. 379-387.

Japan Society of Sleep Research, Handbook of sleep research, Asakura Publishing Co., Ltd. (1999), (in Japanese).

Japan Society of Sleep Research, Clinical evaluation of sleep disorders, Revised edition, Life Science Publishing Co., Ltd. (2015), (in Japanese).

Kambayashi, Y. and Hagiwara, H., Estimating sleep cycle using body movement density, Proceedings of the 20125 th International Conference on Biomedical Engineering and Informatics (2012), pp. 1029-1033.

Kurihara, Y. and Watanabe, K., Development of unconstrained heartbeat and respiration measurement system with pneumatic flow, IEEE Transactions on Biomedical Circuits and Systems, Vol. 6, No. 6 (2012a), pp. 596-604. 
Kurihara, Y. and Watanabe, K., Sleep-stage decision algorithm by using heartbeat and body-movement signals, IEEE Transactions on Systems, Man, and Cybernetics, Part A, Vol. 42, No. 6 (2012b), pp. 1450-1459.

Matsuo, K., Mukai, T., Kato, Y. and Guo, S., Unconstrained measurement of respiration and heartbeat using a flexible tactile sensor sheet on a bed, Transactions of the JSME (in Japanese), Vol. 81, No. 826 (2015), DOI: 10.1299/transjsme.14-00642.

Ministry of Economy, Trade and Industry and Ministry of Health, Labor and Welfare, Japan, Priority areas to which robot technology is to be introduced in nursing care of the elderly (2012), online, available from $<$ http://robotcare.jp/?lang=en >, (accessed on 1 March, 2018).

Ministry of Health, Labour and Welfare, Japan, General welfare and labour (2011), online, available from <http:/www.mhlw.go.jp/english/policy/other/social-security/index.html>, (accessed on 1 March, 2018).

Moriya, A., Suzuki, T., Ouchi, K. and Kameyama, K., Sleep state estimation method using pulse wave and its application, Paper of Human Interface Society, Vol. 10, No. 2 (2008), pp. 207-214 (in Japanese).

Mukai, T., Matsuo, K., Kato, Y., Shimizu, A. and Guo, S., Unconstrained measurement of lying posture, respiration and heartbeat using a tactile sensor on a bed, Transactions of the JSME (in Japanese), Vol. 80, No. 815 (2014), DOI: $10.1299 /$ transjsme.2014bms0215.

National Institute of Population and Social Security Research, Population projections for Japan (January 2012) -2011 to 2060- (2012), online, available from <http://www.ipss.go.jp/site-ad/index_english/esuikei/gh2401e.asp >, (accessed on 1 March, 2018).

Noda, A. and Koike, Y., Polysomnography, Transactions of the Japanese Society for Medical and Biological Engineering: BME, Vol. 46, No. 2 (2008), pp. 134-143 (in Japanese).

Okada, S., Ohno, Y., Goyahan, Kato-Nishimura, K., Mohri, I. and Taniike, M., Examination of non-restrictive and non-invasive sleep evaluation technique for children using difference images, Proceedings of the 30th Annual International Conference of the IEEE Engineering in Medicine and Biology Society (2008), pp. 2483-2487.

Otsuka, K., Ichimaru, Y., Yanaga, T. and Sato, Y., Studies of arrhythmias by 24-hour polygraphic recordings: relationship between atrioventricular block and sleep states, American Heart Journal, Vol. 105, No. 6 (1983), pp. 934-940.

Rechtschaffen, A. and Kales, A., A manual of standardized terminology, techniques and scoring system for sleep stages of human subjects, Bethesda, Md.: U. S. Dept. of Health, Education, and Welfare, Public Health Services-National Institutes of Health, National Institute of Neurological Diseases and Blindness, Neurological Information Network (1968).

Salmi, T. and Leinonen, L., Automatic analysis of sleep records with static charge sensitive bed, Electroencephalography and Clinical Neurophysiology, Vol. 64, No. 1 (1986), pp. 84-87.

Statistics Bureau, Ministry of Internal Affairs and Communications, Japan, The 2010 population census of Japan (2011), online, available from <http://www.stat.go.jp/english/data/kokusei/index.htm>, (accessed on 1 March, 2018).

Watanabe, K., Watanabe, T., Watanabe, H., Ando, H., Ishikawa, T. and Kobayashi, K., Noninvasive measurement of heartbeat, respiration, snoring and body movements of a subject in bed via a pneumatic method, IEEE Transactions on Biomedical Engineering, Vol. 52, No. 12 (2005), pp. 2100-2107.

Watanabe, T. and Watanabe, K., Estimation of the sleep stages by the non-restrictive air mattress sensor: relation bitween the change in the heart rate and sleep stages, Transactions of the Society of Instrument and Control Engineers, Vol. 37, No. 9 (2001), pp. 821-828 (in Japanese).

Watanabe, T. and Watanabe, K., Noncontact method for sleep stage estimation, IEEE Transactions on Biomedical Engineering, Vol. 51, No. 10 (2004), pp. 1735-1748.

Zhu, J., Zou, H., Rosset, S. and Hastie, T., Multi-class AdaBoost, Statistics and its Interface, Vol. 2 (2009), pp. 349-360. 